\title{
Polish students' knowledge of dietary supplements
}

\author{
Barbara Brodziak-Dopierała $^{1}$ (D) $\cdot$ Agnieszka Fischer $^{1}$ (D) $\cdot$ Bożena Ahnert $^{1}$ (D)
}

Received: 13 February 2020 / Accepted: 26 January 2021 / Published online: 24 February 2021

(C) The Author(s) 2021

\begin{abstract}
Background The increasing intake of dietary supplements (DS) can be observed worldwide. These preparations are classified as a special category of foods and are subject to food law, not pharmaceutical regulations. As a result, the requirements for DS are much less restrictive than for medications.

Methodology This research was conducted in a group of young Polish students of pharmacy at the Medical University of Silesia in Katowice (SUM) and of finance and accounting at the University of Economics in Katowice (UE). The survey contained questions concerning DS, such as difference to drugs, scope of use, and safety.

Results The respondents answered questions about taking DS and the effects of their use. DS were used either currently or in the past by about $70 \%$ of the respondents, while about $30 \%$ of the surveyed population declared that they did not use these preparations. Women and UE students predominated among those not taking DS.

Conclusion Multi-component products taken for a period of less than 3 months to supplement a deficit for a given component were used the most often. One product was taken at a time. The respondents read product information and followed the recommended doses. Over $50 \%$ of the studied population was aware of the negative effects of DS. Adverse symptoms of DS use were observed by $5 \%$ of the respondents.
\end{abstract}

Keywords Dietary supplements $\cdot$ Students $\cdot$ Questionnaire $\cdot$ Knowledge

\section{Introduction}

The development of the DS market in Poland in recent years has been a very dynamic process. It is estimated that this market will grow by around $8 \%$ per year in 2017-2020 (NIK 2017). The reason for the rapidly growing sale of supplements is the easy and unlimited access to such products. Every fourth advertisement broadcast on television concerns DS. Aggressive promotional and advertising campaigns by some manufacturers are designed to convince the public that they should buy DS to improve their health, and not only to compensate a deficit (Rzodkiewicz 2019; Pharmatrends 2018).

Unlike medications, DS are not subject to pharmaceutical law but food law. Hence, there are many differences between

Barbara Brodziak-Dopierała

bbrodziak@sum.edu.pl

1 Department of Toxicology and Bioanalysis, Faculty of Pharmaceutical Science, Medical University of Silesia, 4 Jagiellonska Str., 41-200 Sosnowiec, Poland a supplement and a drug. It is a short and inexpensive process to register DS. There are no studies on supplement stability, interaction with drugs and food, or possible side-effects (Bojarowicz and Dźwigulska 2012; Gęiak et al. 2012). An important feature that distinguishes a DS from a drug is the packaging, since DS do not usually contain a package leaflet, which is a legal requirement for a medicinal product. A supplement label has no information on possible side-effects, contraindications and interactions (Krasnowska and Sikora 2011; GIS 2018).

An excessive supply of supplement ingredients such as vitamins, and micro- and macro-nutrients can have the opposite of the desired effect, and even contribute to health complications, such as in the case of calcium and vitamins $\mathrm{D}_{3}, \mathrm{~A}$, E, and pro vitamin A (Chen et al. 2019; Bjelakovic et al. 2007; Rao et al. 2017; Sprouse and Breemen 2016).

Supplements containing natural products, mainly of plant origin, are very popular (Sprouse and Breemen 2016; Tsai et al. 2012). There is a common belief that a natural product is healthy. However, substances contained in plants can also have strong effects and may interact with medications. There can also be toxicity issues with DS based on plants. Studies using in-vitro models have proved their cytotoxicity. The most 
common problems arise with hepatotoxicity, cardiovascular toxicity, and toxicity to the nervous and digestive systems. Hepatotoxicity affects one in five products tested among herbal supplements, and is more common in women $(61 \%)$ (Bjelakovic et al. 2007). What is more, there is very little information in the literature on the subject of minimum toxic or lethal doses. Usually, toxicity and side-effects of DS occur when consumed at doses many times higher than the therapeutic recommendation (Tsai et al. 2012; Zhu et al. 2018; de Boer and Sherker 2017; Frenzel and Teschke 2016; Levy et al. 2017).

Levy et al. (2017) reported that hospitalization of $1 \%$ of people may be associated with an adverse reaction resulting from the interaction between drugs and herbal supplements. Most cases seem to involve an "at least possible" causal effect, especially among patients with multiple comorbidities (de Boer and Sherker 2017).

Agbabiaka et al.'s (2018) research has shown that in the United Kingdom, the frequency of co-administration of prescription drugs and DS was $39 \%$. It is estimated that about $33 \%$ of them are at risk of potential adverse interactions (Agbabiaka et al. 2018).

\section{Material and methods}

The questionnaire was reviewed by the university Bioethics Committee, and the study procedure was conducted in accordance with the requirements of the Medical University of Silesia, Poland. Participation in the study was voluntary, anonymous, and confidential. All students gave their verbal consent and were able to cease participation at any time, or refuse to answer any question without reason. The study was conducted among Polish residents. They were young people, aged 17-28, with an average age of 21 years. The studied population $(n=230)$ were students of pharmacy at the Medical University of Silesia (SUM) $(n=133)$ and students of finance and accounting at the University of Economics in Katowice (UE) $(n=97)$. The average age of SUM students was 22 years and therefore higher than that of UE students, which was 19 years. Women constituted $70 \%$ of the surveyed population, and men $30 \%$. Slightly more women represented the SUM $(73 \%)$ than the UE $(65 \%)$. The participants lived mainly in medium-sized cities $(48 \%)$, followed by villages (29\%), large cities (15\%) and small towns (8\%). See Table 1.

This study involved an anonymous survey conducted from March to December 2019, and comprised 37 questions designed for self-completion by the respondents. It contained metric data describing the participants' sociodemographic data such as age, gender, place of residence, field of study, and health status. It also included questions determining the level of knowledge on supplements, such as definition, legal nomenclature, and scope of application, and about usage, such as frequency, selection criterion, and expected effects. Statistical processing of data was using Statistica ${ }^{\circledR} 13.1$ software (StatSoft, Cracow, Poland). The relations between qualitative features were established by the $\chi^{2}$ test. For low numbers in subgroups, the $\chi^{2}$ test was used with the Yates correction. Results with $p<0.05$ were considered statistically significant.

\section{Results}

The surveyed students described their health mainly as very good $(46 \%)$ and good $(52 \%)$. Poor health was indicated by about $2 \%$ of the studied population. UE students described their health as being slightly better, with no one in this study group characterizing their health as bad. Chronic diseases were declared by $25 \%$ of the respondents, and $19 \%$ of the students surveyed regularly took medication. Over $90 \%$ of the respondents were physically active, with the largest group practicing sport at least once a week. Men (37\%) regularly exercised more often than women (19\%), and UE students more often than SUM students (29\% and $21 \%$ respectively) (Table 1).

DS were used by about $70 \%$ of the respondents, either currently or in the past, while about $30 \%$ of the surveyed population declared that they never used these preparations. Women and UE students predominated among those not taking DS. The differences were not statistically significant.

Student answers to survey questions about taking DS are presented in Table 2. DS were used by $13 \%$ of the surveyed students on a regular basis, and by $27 \%$ sporadically. The largest group (29\%) were people who used DS periodically to supplement a specific deficit. The overwhelming majority of the respondents used one supplementation at a time $(75 \%)$, mainly in the form of tablets $(58 \%)$ or capsules $(26 \%)$. The decision on supplementation was most often taken by the respondents themselves (72\%), and less often on medical advice $(14 \%)$. DS were more often chosen by men compared to women ( $82 \%$ and $68 \%$ respectively). However, women more often paid attention to suggestions made by other people, such as doctors, dietitians, beauticians, or friends.

The majority of students were aware that supplementation preparations are not identical to medicinal products, and $84 \%$ of the respondents knew the definition of DS. Most of them, namely $70 \%$, also consciously chose these preparations instead of medications. However, UE students had a statistically lower level of knowledge in this area than SUM students (47\% and $84 \%$ respectively). The main sources of information about DS were consultation with a pharmacist (51\%) or doctor (19\%), or other people. Thirteen percent of the respondents gained their product information from advertisements. Differences in decision-making about supplementation turned out to be statistically significant for the students of the two 
Table 1 Sociodemographic data of respondents

\begin{tabular}{|c|c|c|c|c|c|c|}
\hline & & All & Women & Men & SUM & UE \\
\hline \multirow{5}{*}{$\begin{array}{l}\text { Place of } \\
\text { residence }\end{array}$} & Village & $29.3 \%$ & $34.2 \%$ & $18.3 \%$ & $34.1 \%$ & $22.7 \%$ \\
\hline & Small city $(<10,000$ residents $)$ & $8.2 \%$ & $8.7 \%$ & $7.0 \%$ & $11.1 \%$ & $4.1 \%$ \\
\hline & $\begin{array}{l}\text { Medium-sized city }(10,000-200,000 \\
\text { residents) }\end{array}$ & $47.8 \%$ & $44.7 \%$ & $54.9 \%$ & $43.0 \%$ & $54.6 \%$ \\
\hline & Large city (>200,000 residents) & $14.7 \%$ & $12.4 \%$ & $19.7 \%$ & $11.9 \%$ & $18.6 \%$ \\
\hline & & & \multicolumn{2}{|l|}{ NS } & \multicolumn{2}{|c|}{$p=0.02669$} \\
\hline \multirow[t]{4}{*}{ Health } & Very good & $46.4 \%$ & $45.1 \%$ & $49.3 \%$ & $44.4 \%$ & $46.0 \%$ \\
\hline & Good & $51.5 \%$ & $53.7 \%$ & $46.5 \%$ & $53.5 \%$ & $54.0 \%$ \\
\hline & Bad & $2.1 \%$ & $1.2 \%$ & $4.2 \%$ & $2.0 \%$ & $0.0 \%$ \\
\hline & & & \multicolumn{2}{|l|}{ NS } & \multicolumn{2}{|l|}{ NS } \\
\hline \multirow{3}{*}{$\begin{array}{l}\text { Chronic } \\
\text { diseases }\end{array}$} & No & $75.4 \%$ & $74.4 \%$ & $77.9 \%$ & $72.7 \%$ & $79.2 \%$ \\
\hline & Yes & $24.6 \%$ & $25.6 \%$ & $22.1 \%$ & $27.3 \%$ & $20.8 \%$ \\
\hline & & & \multicolumn{2}{|l|}{ NS } & \multicolumn{2}{|l|}{ NS } \\
\hline \multirow[t]{3}{*}{ Medications } & No & $80.6 \%$ & $78.0 \%$ & $86.8 \%$ & $76.5 \%$ & $86.3 \%$ \\
\hline & Yes & $19.4 \%$ & $22.0 \%$ & $13.2 \%$ & $23.5 \%$ & $13.7 \%$ \\
\hline & & & \multicolumn{2}{|l|}{ NS } & \multicolumn{2}{|l|}{ NS } \\
\hline \multirow{5}{*}{$\begin{array}{l}\text { Physical } \\
\text { activity }\end{array}$} & Yes, regularly & $24.5 \%$ & $19.3 \%$ & $36.8 \%$ & $21.2 \%$ & $28.9 \%$ \\
\hline & Yes, at least once a week & $45.0 \%$ & $48.5 \%$ & $36.8 \%$ & $36.4 \%$ & $56.7 \%$ \\
\hline & Yes, occasionally & $22.7 \%$ & $24.8 \%$ & $17.7 \%$ & $31.8 \%$ & $10.3 \%$ \\
\hline & Not at all & $7.9 \%$ & $7.5 \%$ & $8.8 \%$ & $10.6 \%$ & $4.1 \%$ \\
\hline & & & \multicolumn{2}{|l|}{$p=0.03433$} & \multicolumn{2}{|c|}{$p=0.00006$} \\
\hline
\end{tabular}

$p$ - level of statistical significance; NS - no statistical significance, $p \geq 0.05$

SUM - students of pharmacy, Faculty of Pharmaceutical Science at Medical University of Silesia in Katowice

UE - students of finance and accounting, College of Finance at University of Economics in Katowice studied faculties. SUM students were most often guided by the opinion of qualified pharmacists. In most cases, students read the product packaging. Approximately $62 \%$ of the respondents, more often students of SUM than UE, did so before consuming a product.

Regarding the frequency of DS use, respondents said that they took preparations periodically to make up for a deficit of a given ingredient in $29 \%$ of cases, and sporadically in $27 \%$ of cases. Regular supplementation was used by $13 \%$ of the respondents, and 32\% declared they did not take any DS. Answers about the frequency of DS use were similar for students of both universities, and for both women and men.

Most students spent about PLN 20.00/\$US 5 per month on DS. The decision to purchase was mainly the result of advice given by a pharmacist $(45 \%)$ or doctor $(18 \%)$. The purchase was primarily prompted by medical indications and the need to quickly supplement nutrient deficiencies, as indicated by almost $50 \%$ of responses. The place of purchase was usually a pharmacy, followed by the Internet, supermarkets, and herbal stores (Table 3 ).

Most of the respondents were convinced of the beneficial effects of supplementation, with about $65 \%$ giving affirmative answers. Of the surveyed group, $26 \%$ did not have an opinion on this subject, and $10 \%$ said that using DS would definitely not bring health benefits. SUM students were especially sceptical in rating the effectiveness of supplementation. In $78 \%$ of responses, supplementation preparations were mainly used in doses recommended by the manufacturers, while $22 \%$ of respondents did not follow the indications on the product packaging. The students participating in the study were aware of potential supplementation-drug interactions. Statistically, there was a significantly higher awareness among SUM students compared to UE students. Most respondents (59\%) were not afraid of the negative effects of DS, including the possibility of overdose (Table 2).

The positive effects of using supplements were observed by around half of the studied population, namely $48 \%$. A small percentage of respondents $(5 \%)$ observed negative effects while using DS - see Table 2. The most commonly reported side-effects were drowsiness, gastrointestinal discomfort including abdominal pain and diarrhea, and menstrual disorders in women.

\section{Discussion}

Many generally healthy people use supplementation to prolong life, delay ageing, lose weight faster, or build muscle 
Table 2 Dietary supplement intake in students

\begin{tabular}{|c|c|c|c|c|c|c|}
\hline Survey question & Response & All & Women & Men & SUM & UE \\
\hline \multirow[t]{5}{*}{ Do you take dietary supplements? } & Yes, regularly & $12.8 \%$ & $10.4 \%$ & $18.3 \%$ & $11.1 \%$ & $15.2 \%$ \\
\hline & Yes, occasionally & $26.9 \%$ & $23.9 \%$ & $33.8 \%$ & $28.9 \%$ & $24.2 \%$ \\
\hline & $\begin{array}{l}\text { Only to supplement a specific } \\
\text { deficiency }\end{array}$ & $28.6 \%$ & $32.5 \%$ & $19.7 \%$ & $29.6 \%$ & $27.3 \%$ \\
\hline & No, not at all & $31.6 \%$ & $33.1 \%$ & $28.2 \%$ & $30.4 \%$ & $33.3 \%$ \\
\hline & & & NS & & NS & \\
\hline \multirow[t]{5}{*}{ Do you use more than one dietary supplement at the same time? } & No & $74.6 \%$ & $77.8 \%$ & $67.1 \%$ & $78.5 \%$ & $69.1 \%$ \\
\hline & Yes, two supplements & $14.7 \%$ & $13.0 \%$ & $18.6 \%$ & $14.1 \%$ & $15.5 \%$ \\
\hline & Yes, three supplements & $5.2 \%$ & $6.2 \%$ & $2.9 \%$ & $4.4 \%$ & $6.2 \%$ \\
\hline & Yes, more than three & $5.6 \%$ & $3.1 \%$ & $11.4 \%$ & $3.0 \%$ & $9.3 \%$ \\
\hline & & & \multicolumn{2}{|c|}{$p=0.03908$} & NS & \\
\hline \multirow[t]{5}{*}{ In what form do you most often take dietary supplements? } & Capsule & $25.9 \%$ & $23.3 \%$ & $31.7 \%$ & $25.6 \%$ & $26.4 \%$ \\
\hline & Pill & $57.7 \%$ & $64.3 \%$ & $43.3 \%$ & $62.4 \%$ & $50.0 \%$ \\
\hline & Powder & $4.8 \%$ & $1.6 \%$ & $11.7 \%$ & $1.7 \%$ & $9.7 \%$ \\
\hline & Other & $11.6 \%$ & $10.9 \%$ & $13.3 \%$ & $10.3 \%$ & $13.9 \%$ \\
\hline & & & \multicolumn{2}{|c|}{$p=0.00409$} & NS & \\
\hline \multirow[t]{5}{*}{ What made you decide to take supplements? } & Own decision & $72.4 \%$ & $67.9 \%$ & $82.3 \%$ & $80.8 \%$ & $57.6 \%$ \\
\hline & Doctor's advice & $13.8 \%$ & $16.4 \%$ & $8.1 \%$ & $9.6 \%$ & $21.1 \%$ \\
\hline & $\begin{array}{l}\text { Dietitian's/cosmetician's } \\
\text { recommendation }\end{array}$ & $1.5 \%$ & $1.5 \%$ & $1.6 \%$ & $0.8 \%$ & $2.82 \%$ \\
\hline & Suggested by others & $12.2 \%$ & $14.2 \%$ & $8.1 \%$ & $8.8 \%$ & $18.3 \%$ \\
\hline & & & NS & & $p=0.00$ & 761 \\
\hline \multirow[t]{6}{*}{ What are you guided by when choosing dietary supplements? } & Pharmacist's advice & $45.5 \%$ & $48.4 \%$ & $39.0 \%$ & $56.0 \%$ & $28.2 \%$ \\
\hline & Doctor's advice & $17.6 \%$ & $21.1 \%$ & $10.2 \%$ & $11.2 \%$ & $28.2 \%$ \\
\hline & Suggested by friends & $9.6 \%$ & $10.2 \%$ & $8.5 \%$ & $7.8 \%$ & $12.7 \%$ \\
\hline & Advertisements & $5.9 \%$ & $5.5 \%$ & $6.8 \%$ & $5.2 \%$ & $7.0 \%$ \\
\hline & Other & $21.0 \%$ & $14.8 \%$ & $35.6 \%$ & $19.8 \%$ & $23.9 \%$ \\
\hline & & & \multicolumn{2}{|c|}{$p=0.02082$} & $p=0.00$ & 227 \\
\hline \multirow{4}{*}{$\begin{array}{l}\text { Do you choose dietary supplements instead of medical drugs } \\
\text { intentionally? }\end{array}$} & Yes & $70.2 \%$ & $69.0 \%$ & $73.0 \%$ & $84.3 \%$ & $47.4 \%$ \\
\hline & No & $8.3 \%$ & $9.2 \%$ & $6.4 \%$ & $3.2 \%$ & $16.7 \%$ \\
\hline & Don’t know & $21.5 \%$ & $21.8 \%$ & $20.6 \%$ & $12.6 \%$ & $35.9 \%$ \\
\hline & & & NS & & $p=0.00$ & \\
\hline \multirow[t]{5}{*}{ Where do you find information about dietary supplements? } & Friends & $16.9 \%$ & $15.6 \%$ & $20.4 \%$ & $12.1 \%$ & $24.7 \%$ \\
\hline & Pharmacist & $50.8 \%$ & $50.4 \%$ & $51.9 \%$ & $61.2 \%$ & $34.3 \%$ \\
\hline & Doctor & $19.0 \%$ & $20.7 \%$ & $14.8 \%$ & $12.1 \%$ & $30.1 \%$ \\
\hline & Advertisements & $13.2 \%$ & $13.3 \%$ & $13.0 \%$ & $14.7 \%$ & $11.0 \%$ \\
\hline & & & NS & & $p=0.00$ & 031 \\
\hline \multirow[t]{3}{*}{ Do you read the list of ingredients? } & Yes & $90.0 \%$ & $89.4 \%$ & $91.2 \%$ & $96.2 \%$ & $80.7 \%$ \\
\hline & No & $10.0 \%$ & $10.6 \%$ & $8.8 \%$ & $3.8 \%$ & $19.3 \%$ \\
\hline & & & NS & & $p=0.00$ & 044 \\
\hline \multirow[t]{4}{*}{ Do you read the leaflet included with the dietary supplement? } & Yes, in detail, before taking & $62.1 \%$ & $64.4 \%$ & $57.4 \%$ & $68.5 \%$ & $52.4 \%$ \\
\hline & $\begin{array}{l}\text { Yes, out of curiosity before } \\
\text { taking }\end{array}$ & $19.6 \%$ & $17.8 \%$ & $23.5 \%$ & $20.8 \%$ & $17.9 \%$ \\
\hline & No & $18.2 \%$ & $17.8 \%$ & $19.1 \%$ & $10.8 \%$ & $29.8 \%$ \\
\hline & & & NS & & $p=0.00$ & 199 \\
\hline \multirow[t]{5}{*}{ How long have you been taking dietary supplements? } & Less than 3 months & $62.9 \%$ & $67.4 \%$ & $51.7 \%$ & $71.1 \%$ & $48.7 \%$ \\
\hline & $3-6$ months & $13.9 \%$ & $12.6 \%$ & $16.7 \%$ & $14.1 \%$ & $13.5 \%$ \\
\hline & $7-12$ months & $4.6 \%$ & $4.4 \%$ & $5.0 \%$ & $2.5 \%$ & $8.1 \%$ \\
\hline & More than 12 months & $18.6 \%$ & $14.8 \%$ & $26.7 \%$ & $12.4 \%$ & $28.4 \%$ \\
\hline & & & \multicolumn{2}{|l|}{ NS } & \multicolumn{2}{|c|}{$p=0.00504$} \\
\hline
\end{tabular}


Table 2 (continued)

\begin{tabular}{|c|c|c|c|c|c|c|}
\hline Survey question & Response & All & Women & Men & SUM & UE \\
\hline Do you believe that dietary supplements are beneficial? & $\begin{array}{l}\text { More yes } \\
\text { Definitely } \\
\text { Don't know } \\
\text { Definitely not }\end{array}$ & $\begin{array}{l}48.9 \% \\
14.7 \% \\
26.2 \% \\
10.2 \%\end{array}$ & $\begin{array}{l}48.7 \% \\
7.7 \% \\
30.8 \% \\
12.8 \% \\
p=0.000\end{array}$ & $\begin{array}{l}49.3 \% \\
30.4 \% \\
15.9 \% \\
4.4 \% \\
02\end{array}$ & $\begin{array}{l}50.0 \% \\
8.2 \% \\
26.9 \% \\
14.9 \% \\
p=0.00\end{array}$ & $\begin{array}{l}47.3 \% \\
24.2 \% \\
25.3 \% \\
3.3 \% \\
080\end{array}$ \\
\hline Do you always take dietary supplements in the recommended doses? & $\begin{array}{l}\text { Yes } \\
\text { No }\end{array}$ & $\begin{array}{l}78.1 \% \\
21.9 \%\end{array}$ & $\begin{array}{l}81.3 \% \\
18.9 \% \\
\text { NS }\end{array}$ & $\begin{array}{l}71.2 \% \\
28.8 \%\end{array}$ & $\begin{array}{l}82.2 \% \\
17.8 \% \\
\text { NS }\end{array}$ & $\begin{array}{l}71.6 \% \\
28.4 \%\end{array}$ \\
\hline Do you notice positive effects when using dietary supplements? & $\begin{array}{l}\text { Yes } \\
\text { No }\end{array}$ & $\begin{array}{l}52.1 \% \\
47.9 \%\end{array}$ & $\begin{array}{l}44.8 \% \\
55.2 \% \\
\text { NS }\end{array}$ & $\begin{array}{l}54.4 \% \\
45.6 \%\end{array}$ & $\begin{array}{l}42.8 \% \\
57.3 \% \\
\text { NS }\end{array}$ & $\begin{array}{l}56.3 \% \\
43.6 \%\end{array}$ \\
\hline Do you notice negative effects when using dietary supplements? & $\begin{array}{l}\text { Yes } \\
\text { No }\end{array}$ & $\begin{array}{l}4.7 \% \\
95.3 \%\end{array}$ & $\begin{array}{l}4.1 \% \\
95.9 \% \\
\text { NS }\end{array}$ & $\begin{array}{l}5.9 \% \\
94.1 \%\end{array}$ & $\begin{array}{l}3.1 \% \\
97.0 \% \\
\text { NS }\end{array}$ & $\begin{array}{l}7.2 \% \\
92.8 \%\end{array}$ \\
\hline Are you aware of the negative effects of using dietary supplements? & $\begin{array}{l}\text { Yes } \\
\text { More yes } \\
\text { More no } \\
\text { No }\end{array}$ & $\begin{array}{l}52.3 \% \\
29.4 \% \\
12.6 \% \\
5.6 \%\end{array}$ & $\begin{array}{l}53.1 \% \\
29.3 \% \\
12.9 \% \\
4.8 \% \\
\text { NS }\end{array}$ & $\begin{array}{l}50.6 \% \\
29.9 \% \\
11.9 \% \\
7.5 \%\end{array}$ & $\begin{array}{l}58.8 \% \\
26.0 \% \\
12.2 \% \\
3.1 \% \\
p=0.04\end{array}$ & $\begin{array}{l}42.2 \% \\
34.9 \% \\
13.3 \% \\
9.6 \% \\
410\end{array}$ \\
\hline $\begin{array}{l}\text { Do you pay attention to the possible interactions of dietary supplements } \\
\text { with medical drugs? }\end{array}$ & $\begin{array}{l}\text { Yes } \\
\text { No }\end{array}$ & $\begin{array}{l}68.4 \% \\
31.6 \%\end{array}$ & $\begin{array}{l}70.8 \% \\
29.3 \% \\
\text { NS }\end{array}$ & $\begin{array}{l}63.2 \% \\
36.8 \%\end{array}$ & $\begin{array}{l}72.0 \% \\
28.0 \% \\
\text { NS }\end{array}$ & $\begin{array}{l}62.7 \% \\
37.4 \%\end{array}$ \\
\hline
\end{tabular}

$p$ - level of statistical significance; NS - no statistical significance, $p \geq 0.05$

SUM - students of pharmacy, Faculty of Pharmaceutical Science at Medical University of Silesia in Katowice

UE - students of finance and accounting, College of Finance at University of Economics in Katowice

mass. It is commonly believed that the level of knowledge on DS among the public is not great, with research by Karbownik et al. (2019) showing that it was poor in people without medical education. The study by Karbownik et al. (2019) found that the average number of correct answers in the 17-element questionnaire about the components of DS, absorption and effects was $8.3 \%$. This reflects the discrepancy between common beliefs and scientific facts, which can be greatly influenced by extensive advertising, often leading to the misconception that the use of DS is good (Kozłowski et al. 2017). The introduction of educational campaigns concerning DS and updating legal regulations can bring beneficial effects. In our research conducted among students, there were no exact questions about the action and absorption of vitamins and substances contained in DS. However, knowledge of what a supplement is and which law it is subject to was demonstrated by as many as $84 \%$ of the respondents.

The use of DS by young people is common both in Poland (Kozłowski et al. 2017; Sigłowa et al. 2009; Krejpcio et al. 2011, 2013; Matysek-Nawrocka et al. 2016; Gajda et al. 2016; Szpringer et al. 2015) and other countries (Beitz et al. 2002; El Khoury et al. 2019; Shade et al. 2019; Naqvi et al. 2018;
Kobayashi et al. 2017; Fattahzadeh-Ardalani et al. 2016; Mughal et al. 2019; Kofoed et al. 2015; Alowais and Selim 2019). They are popular among both older and younger students, with the use of DS in the 13-18 age group being $47 \%$. It has been observed that the use of supplementation is not related to eating habits or place of residence, such as city or village (Gajda et al. 2016).

Kozłowski et al. (2017) conducted a study in a group of young people similar to that surveyed here, in which $67 \%$ of the respondents declared the use of DS. This value is similar to our research, where the frequency of using DS reached $70 \%$. They found that DS were most often bought at the pharmacy (57\%), as we did in our own research $(83 \%)$.

The percentage of observed DS side-effects was slightly higher in Kozłowski et al.'s study (7.4\%) than in our study (5\%) (Kozłowski et al. (2017). In research by Naqvi et al., as many as $24.6 \%$ of respondents reported the occurrence of side-effects after taking supplements (Naqvi et al. 2018).

According to Krejpcio et al. (2013), the intake of DS among students ranged from $47 \%$ up to $61 \%$ and was dependent on the field of study. According to this research, $15 \%$ of the respondents regularly used supplementation. In our own 
Table 3 Purchase of dietary supplements by students

\begin{tabular}{|c|c|c|c|c|c|c|}
\hline Survey question & Response & All & Women & Men & SUM & UE \\
\hline \multirow[t]{6}{*}{$\begin{array}{l}\text { What are you guided by when } \\
\text { choosing dietary supplements? }\end{array}$} & $\begin{array}{l}\text { Pharmacist's } \\
\text { advice }\end{array}$ & $45.5 \%$ & $48.4 \%$ & $39.0 \%$ & $56.0 \%$ & $28.2 \%$ \\
\hline & Doctor's advice & $17.6 \%$ & $21.1 \%$ & $10.2 \%$ & $11.2 \%$ & $28.2 \%$ \\
\hline & $\begin{array}{l}\text { Suggested by } \\
\text { friends }\end{array}$ & $9.6 \%$ & $10.2 \%$ & $8.5 \%$ & $7.8 \%$ & $12.7 \%$ \\
\hline & Advertisements & $5.9 \%$ & $5.5 \%$ & $6.8 \%$ & $5.2 \%$ & $7.0 \%$ \\
\hline & Other & $21.4 \%$ & $14.8 \%$ & $35.6 \%$ & $19.8 \%$ & $23.9 \%$ \\
\hline & & & \multicolumn{2}{|c|}{$p=0.01818$} & \multicolumn{2}{|c|}{$p=0.00250$} \\
\hline \multirow[t]{5}{*}{$\begin{array}{l}\text { What are you guided by when } \\
\text { buying dietary supplements? }\end{array}$} & $\begin{array}{l}\text { Quick correction } \\
\text { of deficit }\end{array}$ & $46.0 \%$ & $43.8 \%$ & $50.8 \%$ & $49.2 \%$ & $40.8 \%$ \\
\hline & Product form & $4.5 \%$ & $2.9 \%$ & $8.2 \%$ & $4.9 \%$ & $4.0 \%$ \\
\hline & Recommendations & $46.0 \%$ & $49.6 \%$ & $37.7 \%$ & $41.8 \%$ & $52.6 \%$ \\
\hline & Advertisements & $3.5 \%$ & $3.7 \%$ & $3.3 \%$ & $4.1 \%$ & $2.6 \%$ \\
\hline & & & \multicolumn{2}{|l|}{ NS } & \multicolumn{2}{|l|}{ NS } \\
\hline \multirow{5}{*}{$\begin{array}{l}\text { Where do you usually buy dietary } \\
\text { supplements? }\end{array}$} & Supermarket & $4.1 \%$ & $1.5 \%$ & $9.4 \%$ & $3.2 \%$ & $5.6 \%$ \\
\hline & Pharmacy & $83.2 \%$ & $93.2 \%$ & $62.5 \%$ & $91.2 \%$ & $69.4 \%$ \\
\hline & Internet & $10.7 \%$ & $5.3 \%$ & $21.9 \%$ & $4.0 \%$ & $22.2 \%$ \\
\hline & Herbalist's & $2.0 \%$ & $0.0 \%$ & $6.3 \%$ & $1.6 \%$ & $2.8 \%$ \\
\hline & & & \multicolumn{2}{|c|}{$p=0.00000$} & \multicolumn{2}{|c|}{$p=0.00049$} \\
\hline \multirow[t]{5}{*}{$\begin{array}{l}\text { How much do you spend on dietary } \\
\text { supplements each month? }\end{array}$} & $\begin{array}{l}\text { Less than PLN } \\
\text { 20/\$US } 5\end{array}$ & $65.9 \%$ & $72.9 \%$ & $50.8 \%$ & $77.1 \%$ & $47.5 \%$ \\
\hline & $\begin{array}{l}\text { PLN 20-50/\$US } \\
\quad 6-12\end{array}$ & $22.3 \%$ & $18.1 \%$ & $31.3 \%$ & $17.6 \%$ & $30.0 \%$ \\
\hline & $\begin{array}{l}\text { PLN } 50-100 / \$ U S \\
13-24\end{array}$ & $7.6 \%$ & $6.9 \%$ & $9.0 \%$ & $2.3 \%$ & $16.3 \%$ \\
\hline & $\begin{array}{c}\text { More than PLN } \\
100 / \text { \$US } 25\end{array}$ & $4.3 \%$ & $2.1 \%$ & $9.0 \%$ & $3.1 \%$ & $6.3 \%$ \\
\hline & & & \multicolumn{2}{|c|}{$p=0.00630$} & \multicolumn{2}{|c|}{$p=0.00002$} \\
\hline
\end{tabular}

$p$ - level of statistical significance; NS - no statistical significance, $p \geq 0.05$

SUM - students of pharmacy, Faculty of Pharmaceutical Science at Medical University of Silesia in Katowice

UE - students of finance and accounting, College of Finance at University of Economics in Katowice survey, systematic DS consumption was declared by $11 \%$ of SUM students and $15 \%$ of UE students. Men were more likely to take supplements regularly than women (18\% vs $10 \%$ respectively). This information is consistent with an investigation by Naqvi et al. (2018). However, in other analyses (Kozłowski et al. 2017; Krejpcio et al. 2013), women were more likely to take DS. Another study by Szpringer et al. (2015) showed that DS consumption was high, with over $20 \%$ of respondents using supplementation several times a year and only $6 \%$ not using DS at all.

Our results showed that participants most often decide to use DS on their own. This was declared to be the case by around $81 \%$ of SUM students and $58 \%$ of UE students. Similarly, research by Krejpcio et al. (2013) showed that $56 \%$ of dietetics students and $51 \%$ of psychology students used DS on their own initiative without consulting a doctor.

Interesting results concerning sports people were presented by Krejpcio et al. (2011), wherein all respondents declared taking DS. They made their decisions mainly under the influence of recommendations from trainers $(72 \%)$ or friends
$(60 \%)$. Very few of these people (around 4\%) consulted a doctor or dietitian about the consumption of DS. This behavior is most likely caused by a lack of knowledge on DS, with less than half of those surveyed knowing the definition of a supplement, and respondents accessing information about DS mainly from the Internet (76\%) (Krejpcio et al. 2011). In our research, students obtained knowledge about supplements primarily from pharmacists ( $51 \%$ of responses).

In the case of active people, positive assessments of the effects of DS were high (84\%) (Krejpcio et al. 2011), while among the students surveyed it was $52 \%$. At almost identical levels of about $50 \%$, students were aware of the risks arising from the use of DS, both among our respondents and in Krejpcio et al.'s (2011) research. It has been observed that $70 \%$ of people practising sport consider DS necessary for their physical activity. What is more, it was found that these people exceeded the recommended dose by $78 \%$. This resulted in side-effects after taking DS in up to $64 \%$ of cases (Krejpcio et al. 2011). In contrast, we found negative effects were declared by only $5 \%$ of the students surveyed, with $78.1 \%$ adhering to the recommended doses of the preparations. 
El Khoury et al. (2019) also conducted research among sports students and, similar to the investigation by Krejpcio et al. (2011), found that among active athletes $100 \%$ of the respondents consumed DS. DS consumption increased in line with age (18-20 years $(57.1 \%), 21-23$ years $(93.9 \%) 24$ 26 years $(100 \%)$ and $>27$ years $(100 \%)$ ) (El Khoury et al. 2019).

Before using DS, one study found that about $20 \%$ of the respondents always read the attached leaflet and over 33\% almost always did so (Szpringer et al. 2015). In our survey $62 \%$ of the students declared that they read the leaflet in detail before taking the product, and $20 \%$ after taking it.

In research by Sigłowa et al. (2009), the average consumption of DS among students of various disciplines was $38 \%$. The lowest was recorded among students in technical fields $(7 \%)$ and the highest for pharmacy students $(45 \%)$. Figures were almost identical for both sexes. The difference between the two study areas was statistically significant (Sigłowa et al. 2009). In our research, however, no statistically meaningful differences were found between the responses of SUM and UE students. As for the type of DS consumed, $60 \%$ were vitamin preparations and 50\% mineral preparations in Sigłowa's study (Sigłowa et al. 2009). This is similar to our research, where the reason for using DS for $51 \%$ of the respondents was vitamin and microelement supplementation, with $17 \%$ taking preparations for improving skin, hair,or nails, and $16 \%$ for increasing immunity - see Fig. 1. Also, according to Fattahzadeh-Ardalani et al. (2016), students most often used substances containing multivitamins and iron.
Similarly to Poland, an increasing consumption of DS has also been observed in Saudi Arabia (Al-Tamim 2019). Research among female students showed that $100 \%$ had in the past used DS and over $30 \%$ were doing so at the time of the research. Supplementation was used mainly for aesthetic reasons, such as improving the condition of the skin, hair, or nails, and the purchase of these products was made in pharmacies. Almost all respondents knew the definition of DS, and half considered them safe. Over one third of the respondents consumed more than one preparation at a time (Al-Tamim 2019). In our research, $75 \%$ of the students took only one supplement preparation, while 15\% took two preparations.

Alowais and Selim (2019) conducted research in Saudi Arabia among students of health sciences and in a group of other students. Disparities in DS intake in both groups were small, being 53\% among students of health sciences, and 56\% in the other group. As in our research, multivitamins were the most commonly used supplement among both UE and SUM students (51\% and $49 \%$ respectively). However, the difference in knowledge on supplementation between students of health sciences and other people was determined to be statistically significant $(p<0.05)$ (Alowais and Selim 2019). Referring to our results, it can be stated that SUM students always demonstrated greater knowledge of DS compared to UE students. Statistically significant differences between the examined groups occurred in the case of decisions on the use of supplements and on the choice of supplement, awareness of how a supplement differs from a drug, beneficial effects, and awareness of negative effects (Table 2).

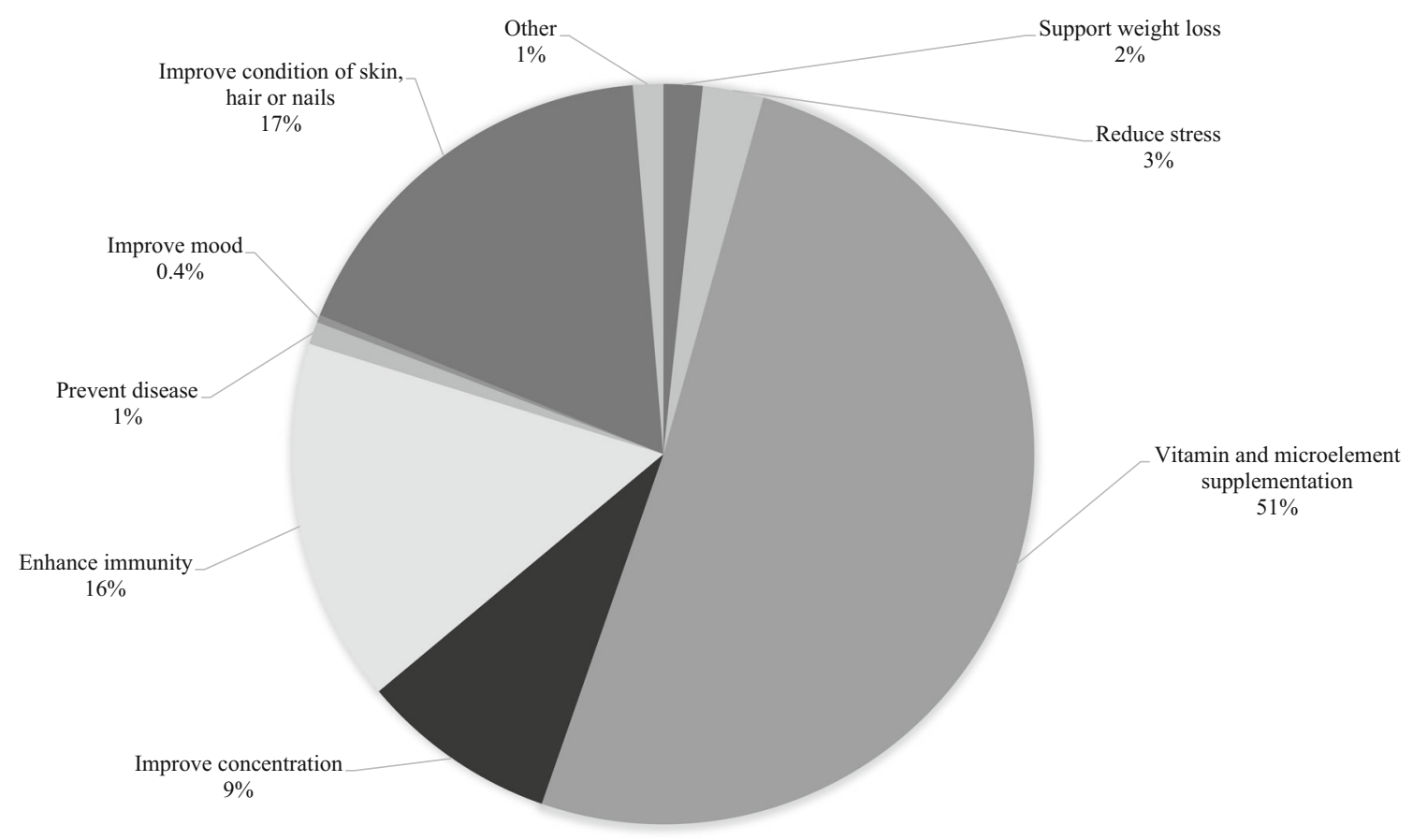

Fig. 1 Reasons for using dietary supplements 
Fattahzadeh-Ardalani et al. surveyed students in Iran in 2016. The frequency of DS use was $66 \%$ among people aged 19-35. The influence of age, sex, BMI, income, and marital status on the use of DS was investigated. Married men and women used DS 1.5 times more often than single women. However, no differences were found for the level of education (Fattahzadeh-Ardalani et al. 2016).

Results by Mughal et al. (2019) for students of various medical faculties in Pakistan showed that $79 \%$ of the respondents had used DS in the last year. Knowledge on DS turned out to be very good in $56 \%$ and excellent in $18 \%$ of participants (Mughal et al. 2019). Pakistani students of pharmacy showed a slightly lower frequency of DS consumption. In this group, DS were used by $48 \%$ of the respondents, $51 \%$ men and $47 \%$ women (Naqvi et al. 2018). The reason for using DS was mainly medical indications $(25 \%)$, which is different than in our study, where the students were guided by this recommendation in less than $10 \%$ of cases. Most of the surveyed students, namely $81 \%$, made supplementation decisions themselves. Naqvi et al. (2018) surveyed students who were older than in our study, and found there was a decrease in the consumption of DS. The percentage of adverse effects after taking supplements was 24\% (Naqvi et al. 2018), much higher than in our research, where the rate was about $5 \%$. The main undesirable side-effects reported by students included gastrointestinal complaints, such as nausea and diarrhea, as well as stomach ache (Naqvi et al. 2018).

The results of an online survey conducted by Kobayashi et al. (2017) showed that in Japan only $16 \%$ of teenagers aged 18-24 use DS, with slightly more men (17\%) than women (16\%) doing so. The popularity of supplementation varied depending on the field of education and, as in this research, medical and pharmacy students consumed DS more often (22\%) than non-medical students (17\%). As in other research, the most commonly used were vitamin and mineral preparations, followed by protein and slimming supplements (Sigłowa et al. 2009; Kofoed et al. 2015; Al-Tamim 2019). The main purpose for using DS was found to be the same as in other research, namely compensating vitamin and mineral deficiencies, as well as increasing muscle mass and in order to lose weight. The respondents most often used information that was posted online (38\%). They usually bought DS in pharmacies or drugstores $(64 \%)$, and $7 \%$ of the students surveyed noticed side-effects (Kobayashi et al. 2017).

\section{Conclusion}

Young people, in our case students, possessed knowledge on supplements, and the positive and negative effects of their use. They consciously chose supplements instead of medicines. SUM students had more knowledge about DS than UE students. These differences were statistically significant.
Half of the respondents believed that taking DS is beneficial to health. The decision on supplementation was most often made by the respondents themselves. There was a statistically significant difference in the number of SUM students electing to take DS on their own compared to UE students. When choosing preparations, all students also sometimes consulted a pharmacist or a doctor. Media advertising encouraged $13 \%$ of the respondents to make DS purchases. The pharmacy was the main place to buy supplements.

Multi-component products taken periodically for less than 3 months to supplement a specific deficit were the most popular. The surveyed students most often took one preparation at a time. They read information about the products they used and adhered to the recommended doses. Over $50 \%$ of the surveyed population was aware of the potential negative effects of DS use, and these were observed by $5 \%$ of the respondents.

Author contributions Barbara Brodziak-Dopierała and Agnieszka Fischer conceived and designed the experiments. Barbara BrodziakDopierała and Agnieszka Fischer performed the experiments, analyzed the data and wrote the paper. Bożena Ahnert entered the data. All authors read and approved the manuscript.

This study was approved by the university Bioethics Committee, and the study procedure was conducted in accordance with the requirements of the Medical University of Silesia.

\section{Declarations}

Financial disclosure The authors have no financial disclosures relevant to this study.

Conflict of interest The authors declare that they have no conflict of interest.

Open Access This article is licensed under a Creative Commons Attribution 4.0 International License, which permits use, sharing, adaptation, distribution and reproduction in any medium or format, as long as you give appropriate credit to the original author(s) and the source, provide a link to the Creative Commons licence, and indicate if changes were made. The images or other third party material in this article are included in the article's Creative Commons licence, unless indicated otherwise in a credit line to the material. If material is not included in the article's Creative Commons licence and your intended use is not permitted by statutory regulation or exceeds the permitted use, you will need to obtain permission directly from the copyright holder. To view a copy of this licence, visit http://creativecommons.org/licenses/by/4.0/.

\section{References}

Agbabiaka TB, Spencer NH, Khanom S, Goodman C (2018) Prevalence of drug-herb and drug-supplement interactions in older adults: a cross-sectional survey. Br J Gen Pract 68 (675): e711-e717. https://doi.org/10.3399/bjgp18X699101 
Alowais MA, Selim MA (2019) Knowledge, attitude, and practices regarding dietary supplements in Saudi Arabia. J Fam Med Prim Care $8: 365-372$

Al-Tamim JZ (2019) Awareness of the consumption of dietary supplements among students in a university in Saudi Arabia. J Nutr Met 2019:4641768. https://doi.org/10.1155/2019/4641768

Beitz R, Mensink GBM, Fischer B, Thamm M (2002) Vitamins - dietary intake and intake from dietary supplements in Germany. Eur J Clin Nutr 56:539-545

Bjelakovic G, Nikolova D, Gluud LL, Simonetti RG, Gluud C (2007) Mortality in randomized trials of antioxidant supplements for primary and secondary prevention: systematic review and meta-analysis. JAMA 297(8):842-857. https://doi.org/10.1001/jama.297.8.842

Bojarowicz H, Dźwigulska P (2012) Suplementydiety. Część I. Suplementydiety a leki - porównaniewymagańprawnych. Hygeia Public Health 47(4):427-432

Chen F, Du M, Blumberg JB, Ho Chui KK, Ruan M, Rogers G, Shan Z, Zeng L, Zhang FF (2019) Association among dietary supplement use, nutrient intake and mortality among U.S. adults. A cohort study. Ann Intern Med 170(9):604-613. https://doi.org/10.7326/M182478

De Boer YS, Sherker AH (2017) Herbal and dietary supplement-induced liver injury. Clin Liver Dis 21(1):135-149. https://doi.org/10.1016/j. cld.2016.08.010

El Khoury D, Dwyer JJM, Fein L, Brauer P, Brennan S, Alfar I (2019) Understanding the use of dietary supplements among athlete and non-athlete university students: development and validation of a questionnaire. Sports 7(7):166. https://doi.org/10.3390/ sports 7070166

Fattahzadeh-Ardalani G, Farzaneh E, Fathi A, Molaei B, Valizadeh M (2016) Determining the prevalence of dietary supplement consumption among Ardabil University students and related factors, 2014. Int J Community Med Public Health 3(1):224-229

Frenzel C, Teschke R (2016) Herbal hepatotoxicity: clinical characteristics and listing compilation. Int J Mol Sci 17(5):588. https://doi.org/ 10.3390/ijms17050588

Gajda K, Zielińska M, Ciecierska A, Hamułka J (2016) Determinants of the use of dietary supplements among secondary and high school students. Rocz Panstw Zakl Hig 67(4):383-390

Gęsiak K, Kondrat M, Stefańczyk-Kaczmarzyk J (2012) Prawo suplementów diety. Wolters Kluwer, Warszawa, pp 16-27

GIS (2018) Zasady wprowadzania po raz pierwszy do obrotu suplementu diety, środków spożywczych specjalnego przeznaczenia żywieniowego oraz żywności wzbogaconej. https://suplementy.gis. gov.p1/. (Accessed 14 Jan 2020)

Karbownik MS, Paul E, Nowicka M, Nowicka Z, Kowalczyk RP, Kowalczyk E, Pietras T (2019) Knowledge about dietary supplements and trust in advertising them: development and validation of the questionnaires and preliminary results of the association between the constructs. PLoS ONE 14(6):e0218398. https://doi.org/10.1371/ journal.pone. 0218398

Kobayashi E, Sato Y, Umegaki K, Chiba T (2017) The prevalence of dietary supplement use among college students: a nationwide survey in Japan. Nutrients 9(11):1250. https://doi.org/10.3390/nu9111250

Kofoed ChLF, Christensen J, Dragsted LO, Tjønneland A, Roswall N (2015) Determinants of dietary supplement use - healthy individuals use dietary supplements. Br J Nutr 113(12):1993-2000. https:// doi.org/10.1017/S0007114515001440

Kozłowski P, Kozłowska M, Kozłowska K (2017) Evaluation of the prevalence of dietary supplement consumption in selected group of young adults. J Edu Health Sport 7(8):106-113. https://doi.org/ 10.5281 /zenodo. 843591
Krasnowska G, Sikora T (2011) Suplementy diety a bezpieczeństwokonsumenta. Żywność Nauka Technol Jakość $4(77): 5-23$

Krejpcio Z, Skwarek K, Hyżyk A, Dyba S (2011) Evaluation of prevalence of dietary supplements intake in a selected group of sports people [in Polish]. Probl Hig Epidemiol 92(4):935-938

Krejpcio Z, Staniek H, Chmielewska A (2013) Evaluation of the prevalence of dietary supplement consumption in selected groups of students [in Polish]. Probl Hig Epidemiol 94(3):622-625

Levy I, Attias S, Ben-Arye E, Goldstein L, Schiff EA (2017) Adverse events associated with interactions with dietary and herbal supplements among inpatients. Br J Clin Pharmacol 83(4):836-845. https://doi.org/10.1111/bcp.13158

Matysek-Nawrocka M, Bernat M, Dyczewski B, Chmiel A (2016) The popularity of dietary supplements among adult Poles [in Polish]. Zeszyty Naukowe Wyższej Szkoły Nauk Społecznych 1(5):145152

Mughal Q, Qura U, Tanveer E, Rashad A, Malik SH, Noreen A, Khan S (2019) Knowledge and consumption of dietary supplement among medical students. Int J Sci Eng Res 10(5):1196-1199

Naqvi AA, Ahmad R, Zehra F, Yousuf R, Kachela B, Nadir M (2018) Dietary supplement use among students of pharmacy colleges in the city of Karachi, Pakistan: prevalence, opinions, and attitudes. J Diet Suppl 16(2):166-178. https://doi.org/10.1080/19390211.2018. 1443191

NIK (2017) Dopuszczanie do obrotu suplementów diety. NIK, Łódź, Poland. https://www.nik.gov.pl/plik/id,13031,vp,15443.pdf (Accessed 13 Jan 2020)

Pharmatrends (2018) Rynek suplementów diety w Polsce 2016. https:// pharmatrends.pl/rynek-suplementow-diety-w-polsce-2018infografika/ (Accessed 13 Jan 2020)

Rao N, Spiller HA, Hodges NL, Chounthirath T, Casavant MJ, Kamboj AK, Smith GA (2017) An increase in dietary supplement exposures reported to US poison control centers. J Med Toxicol 13(3):227237. https://doi.org/10.1007/s13181-017-0623-7

Rzodkiewicz P (2019) Bezpieczeństwo i ryzyka stosowania suplementów diety. GIS, Warszawa

Shade M, Witry M, Robinson K, Kupzyk K (2019) Analysis of oral dietary supplement use in rural older adults. J Clin Nurs 28:1600 1606

Sigłowa A, Bertrandt B, Conder M, Bertrandt K, Lisiecka A, Kubiak P, Urbańska A (2009) Suplementacjadietywśródstudentów. Żywność Nauka Technol Jakość 4(65):236-249

Sprouse AA, van Breemen RB (2016) Pharmacokinetic interactions between drugs and botanical dietary supplements. Drug Metab Dispos 44 (2):162-171. https://doi.org/10.1124/dmd.115.066902

Szpringer M, Olędzka M, Kosecka J, Galińska EM, Chmielewski J, Sobczyk B, Wawrzeńczyk M (2015) Stosowanie leków dostępnych bez recepty i suplementów diety przez osoby dorosłe z województwa świętokrzyskiego. Medycyna Ogólna i Nauki o Zdrowiu 21(2):163-167

Tsai HH, Lin HW, Simon Pickard A, Tsai HY, Mahady GB (2012) Evaluation of documented drug interactions and contraindications associated with herbs and dietary supplements: a systematic literature review. Int J Clin Pract 66(11):1056-1078. https://doi.org/10. 1111/j.1742-1241.2012.03008.x

Zhu J, Seo JE, Wang S, Ashby K, Ballard R, Yu D, Ning B, Agarwal R, Borlak J, Tong W, Chen M (2018) The development of a database for herbal and dietary supplement induced liver toxicity. Int J Mol Sci 19(10):2955. https://doi.org/10.3390/ijms19102955

Publisher's note Springer Nature remains neutral with regard to jurisdictional claims in published maps and institutional affiliations. 